\title{
Cathy Carpenter \\ Celebrating Constitution Day \\ An opportunity to expand our role and increase our value to the campus and to the community
}

M any librarians are not aware of recent legislation Public Law 108-447, Consolidated Appropriations Act 2005 that states, "Each educational institution that receives federal funds for a fiscal year shall hold an educational program on the United States Constitution on September 17 of such year for the students served by the educational institution." This applies to both public and private institutions that receive federal money. The idea of celebrating Constitution Day on September 17 has been around for a while, but it did not become a requirement until 2005. ${ }^{1}$

I believe Constitution Day presents the perfect opportunity for academic libraries to expand our civic role and increase our value to the campus and to the community. From personal experience, I have learned that administrators and faculty are more than happy to have librarians become involved and assume responsibility for planning the programs and events for Constitution Day.

Fortunately, the federal legislation establishing Constitution Day is very nonspecific, a university or college can do just about anything to celebrate the day and meet the requirements of the law. The level of programming can be as minimal as watching some videos from C-SPAN on Constitution topics to having a book display. The flexibility of the law means that even small libraries or libraries with limited staff and resources can become involved.

\section{Constitution Day at Georgia Tech}

I became aware of Constitution Day at my university, Georgia Institute of Technology, two years ago when I read about it in the student newspaper. To celebrate Constitution Day, a few professors from the public policy and literature departments created a Constitution Alley, which consisted of displaying eight large poster boards with an issue such as evolution, genetic engineering, or affirmative action written on each board. The boards were located on a popular student walkway. Students were encouraged to use sticky notes to write their thoughts on the issue and to read and respond to other students' notes. I thought Constitution Alley seemed like a great way to get students thinking about current legal and political issues and how they directly affect them. I wanted to get involved in planning Constitution Day on our campus.

\section{Enlisting faculty}

I knew the faculty member on the planning committee since one of my job responsibilities is to be the liaison to the public policy department. I told him I would like to be involved in next year's planning and the library would be the perfect venue to sponsor and organize the programs and events. He welcomed my involvement and we met last summer as a committee of two. We could not accomplish much with just the two of us, so we discussed what individuals we would ask to serve on our committee. He was very blatant about the difficulty of getting teaching faculty involved on campus and was pessimistic about find-

Cathy Carpenter is head of Architecture Library at Georgia Institute of Technology, e-mail: cathy. carpenter@library.gatech.edu

๑ 2008 Cathy Carpenter 
ing others to help us. Obviously, he had not worked with librarians before! I assured him that not only could I enlist several competent librarians and library staff, but that they would be enthusiastic, as well.

I asked two librarians who I knew were interested in civic and political issues and two library staff, one who had exhibit skills and the other who was responsible for event planning in the library's newest information commons area. Our committee of six met regularly over the summer months. During our first few meetings we gathered ideas from looking at Web sites for Constitution Day resources such as the New York Times Constitution Day Planning Web site. ${ }^{2}$

We then had a brainstorming session where we explored what was possible, considering the limitations of our resources and the amount of time each committee member could devote. We narrowed our list of activities to what was viable but also ones that would use the expertise of the committee members.

\section{Our topic}

We wanted to have an educational lecture that would be of interest to students that would focus on a hot topic in the news. We chose the topic of unlawful government surveillance viewed from a historical perspective. The professor on our committee had a law degree and was knowledgeable about constitutional issues. He and another legal instructor in the public policy department each gave a lecture during the week. The first presentation was called "Privacy Please! Part I: A Constitutional History of Wiretapping" and the second was titled "Privacy Please! Part II: Who's Listening Now?"
Our exhibit expert suggested we create several informational panels highlighting various constitutional issues. We settled on the following topics: the Fifth Amendment, the Eighteenth Amendment, privacy rights, and voting rights. Each panel was 24 x 36-inch poster size with text describing the constitutional topic and how it is still relevant today. We had an attention grabbing photo at the top of each panel. The panels were displayed in our busy information commons area, very close to where the lectures would be taking place. We also had our library Webmaster add a Constitution Day Q \& A page to our library Web site.

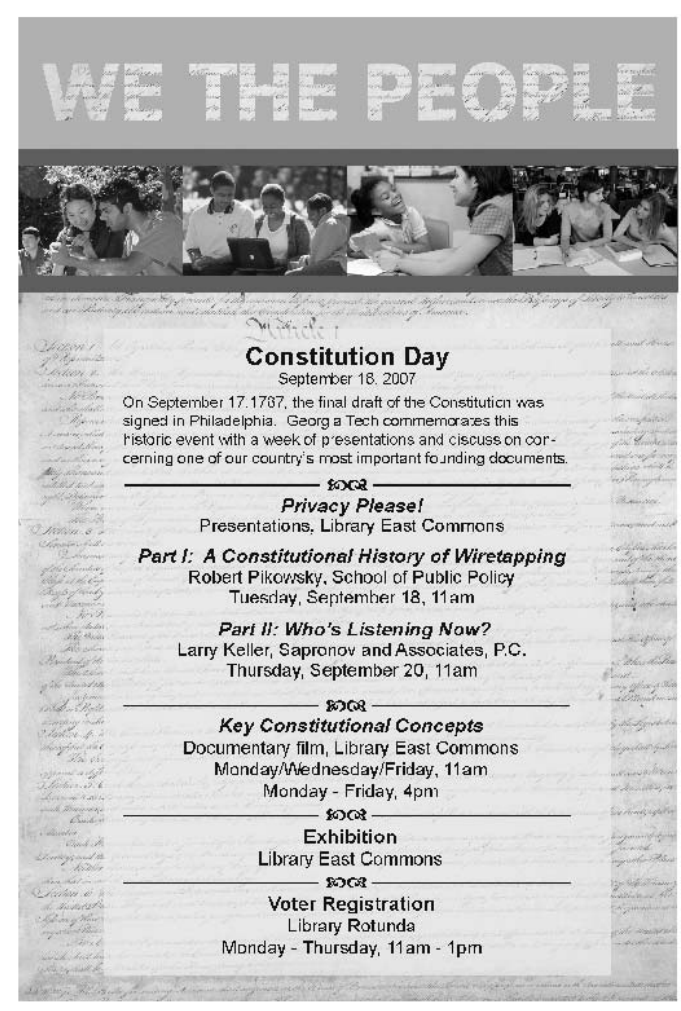

During our search of Constitution Day resources we came across the Web site Annenberg Classroom: Resources for America's Teachers and decided to purchase two 20-minute videos called "Key Constitutional Concepts" that we showed throughout the week on the large screen in the presentation/lecture corner of our information commons. ${ }^{3}$ The videos were our only expense. We had a budget from the university of several hundred dollars but were able to do everything in-house, including developing the informational exhibit panels.

In the past, I had organized campus voter registration drives with our student government association and suggested I could do that again during the week of September 17. I only needed to get the registration forms and find a few library staff members to help me staff a voter registration table in the library entrance.

The final step was to publicize the Constitution Day events on campus. The first week in September, I contacted Technique, the 
campus student newspaper, to do a feature article about the upcoming events. We developed promotional flyers and placed them in the student center, the student recreation center, and the library reference and circulation desks. Our library Webmaster placed a promo for the events on the library Web site and also on the campus calendar. We also ran off enough flyers to have the housing TA's distribute them in the student dorms. ${ }^{4}$

We were pleased with the turnout for the Constitution Day events. The two lectures were well attended by both students and faculty, and there were plenty of questions afterwards from the audience. Several students commented on the informational panels during the week. I was able to register quite a few students and answered a lot of questions about registration in general and absentee voting.

\section{Outcomes}

The benefits of the library organizing Constitution Day are readily apparent: it increases the libraries' visibility on campus and with university administrators; provides opportunities to collaborate with other departments, such as the political science department or the university law school as well as student groups (debate team or student government association); promotes constitutional literacy and encourages student voter participation.

One of the best things about Constitution Day is the flexibility of the federal regulation, a library could put as much effort into programming as its resources allow. Of course the library could do the same thing each year (which I would not recommend) or experiment with different events, exhibits, films, lectures, and debates depending on what constitutional topics are currently in the news. Since the Constitution is the basis of our legal system, the topics would always be relevant. One year privacy issues may be in the news, another year could be immigration laws or stem cell research. This being an election year, legal issues dealing with voting rights such as the proposed voter ID law or problems with voter fraud and electronic voting would be timely topics.

\section{Partnerships beyond the academy}

All librarians are familiar with information literacy initiatives that prepare students to be competent information seekers in the digital age. Another form of literacy is civic literacy, which strives to ensure students have the political knowledge and skills to participate as active citizens in our democracy. Constitution Day programming can go a long way to fulfill the civic literacy imperative for our students.

Traditionally, academic libraries have focused primarily on their campus constituents of students and faculty, but many university libraries have been connecting for years with their local communities by serving as federal depositories of government information. Since this is an election year, all academic libraries have a unique opportunity to organize and promote civic literacy not only for students at their institutions, but also to move beyond the academy and build partnerships with influential organizations in their communities.

Promoting civic education has long been one of the core missions of public libraries. Many public libraries have a long history of sponsoring community programs that educate citizens about local and national issues and facilitates dialogue. Nancy Kranich, past ALA president and a major proponent of encouraging academic libraries to become involved with civic literacy and engagement initiatives, has written extensively on the topic..$^{5}$ Academic libraries could collaborate with public libraries to host an exhibit that explores democracy, freedom of speech, or civil rights that would be of interest to the campus and the community.

Other potential partnerships could include collaborating with a local museum, historical center, or the state archive to share resources, such as historical documents or a news archive. Academic libraries could also partner with civic organizations, such as the local League of Women Voters, and sponsor panel 
discussions, debates, or lectures featuring local and state political candidates discussing the relevant issues.

For the last few years, both public and academic libraries have been participating in an initiative called the September Project ,which is a grassroots effort to foster civic events in all communities on the day of September $11 .{ }^{6}$ Libraries are encouraged to offer programs that explore themes of democracy, citizenship, and patriotism. Civic literacy programs don't only have to be offered during the autumn months.

In March, the National Freedom of Information Day (sponsored by the First Amendment Center in Nashville) and Sunshine Week (sponsored by the American Society of Newspaper Editors) provide opportunities for academic libraries to partner with newspaper and media organizations to educate the public about the importance of open government and keeping information freely accessible. ${ }^{7}$

Thomas Jefferson said, "I know of no safe repository of the ultimate power of society but people. And if we think them not enlightened enough, the remedy is not to take the power from them, but to inform them by education."

Constitution Day offers librarians the perfect opportunity to educate and inform our users, form meaningful collaborations, and to extend our sphere of influence. Why not get involved this year? You have nothing to lose.

\section{Notes}

1. Constitution Day announcement in Federal Register, www.ed.gov/legislation /FedRegister/other/2005-2/052405b.html (accessed January 3, 2008).

2. New York Times Constitution Day Planning Guide Web site, www.nytimes.com/ref /college/collegespecial2/coll-constitutionday. html (accessed January 3, 2008).

3. Annenberg Classroom: Resources for America's Teachers Web site, www. annenbergclassroom.org/Chapter.aspx?Id=61 (accessed January 3, 2008).

4. Georgia Tech Constitution Day promotional flyer, www.library.gatech.edu/news /docs/constitution_flyer.pdf.

5. Nancy Kranich, Michele Reid, and Taylor Willingham, "Civic Engagement and Academic Libraries," College and Research Libraries News, vol. 65, \#4 (July/August, 2004): 380-83, 388, 393, www.ala.org/ala/acrl /acrlpubs/crlnews/backissues2004/july04 /civicengagement.cfm (accessed January 3, 2008).

6. The September Project Web site, theseptemberproject.wordpress.com/ (accessed January 3, 2008).

7. National Freedom on Information Day Web site, www.firstamendmentcenter.org /press/information/topic.aspx?topic $=$ FO I_Day (accessed January 3, 2008). Sunshine Week Web site, www.sunshineweek.org/ (accessed January 3, 2008).

8. Thomas Jefferson quote, found at www.wisdomquotes.com/003263.html (accessed January 3, 2008). 